\title{
Pendekatan Fenomenologi dalam Studi Islam
}

\author{
Sihabuddin \\ STKIP PGRI Sumenep \\ email: udinsihabuddin@yahoo.com
}

\begin{abstract}
Abstrak :
Agama adalah anugerah Allah swt yang diperuntukkan kepada manusia (umat Islam) sebagai penuntun agar mendapatkan keselamatan di dunia dan akhirat, karena dalam agama Islam ada aturan-aturan yang harus dijalani oleh individu maupun kelompok agar bisa membedakan mana yang baik (konstruktif-moralis) dan mana yang buruk (degradasi-immoralis). Meskipun demikian, mempelajari agama yang mengkolaborasikan ilmu pengetahuan bukanlah sesuatu yang dilarang. Bahkan, korelasi antara agama dengan ilmu pengetahuan merupakan sesuatu yang sangat mungkin dibawa oleh para sarjana agama, termasuk dalam Islam. Pemahaman terhadap agama Islam yang beberapa dekade cenderung "teologis-normatif" telah menutup para pemikir agama Islam untuk melakukan studi terhadap fenomena agama Islam, seperti memahami praktik ajaran agama yang cenderung bersifat ritual yang ada di masing-masing pemeluk agama Islam itu sendiri. Untuk memahaminya, maka diperlukan metode khusus yang disebut dengan "fenomenologi", dimana metode ini menggambarkan pengalaman praktik keagamaan penganut agama secara sadar terhadap fenomena keagamaan yang dijalankan.
\end{abstract}

Kata Kunci : Fenomenologi, Agama, Studi Islam

\begin{abstract}
Religion is the gift of God Almighty which is intended for humans (Muslims) as a guide to get safety in the world and the hereafter, because in Islam there are rules that must be followed by individuals and groups in order to distinguish between good (constructive-moralist) and which is bad (degradation-immoralis). Nevertheless, studying religion that collaborates science is not something that is prohibited. In fact, the correlation between religion and science is something that is very likely to be carried by religious scholars, including in Islam. Understanding of the Islamic religion which has tended to be "theologically-normative" for decades has closed Islamic thinkers to study the phenomenon of Islam, such as understanding the practices of religious teachings that tend to be ritualistic in each of the Muslims themselves. To understand it, a special method is needed called "phenomenology", where this method describes the experience of the religious practice of religious adherents consciously of the religious phenomena that are carried out.
\end{abstract}

Keyword: Phenomenology, Religion, Islamic Studies

108 Autentik: Jurnal Pengembangan Pendidikan Dasar, Vol.2, No.2, Juli 2018 


\section{Pendahuluan}

Manusia adalah makhluk Allah swt yang paling mulia diantara makhluk yang lain karena dibekali dengan kemampuan berfikir (aql) dan diberi nafsu/keinginan diri didalam hidup untuk melakukan berbagai hal yang dipandang baik (bermoral) dalam tatanan hidup dalam masyarakat yang didasarkan dengan norma sosial dan agama. Satu sisi, karena manusia sebagai makhluk sosial, sudah sejatinya melakukan interaksi sosial dengan manusia lainnya sebagai wujud jati diri (kodrat) manusia itu sendiri hidup di dunia (yang) tidak bisa hidup sendiri, tetapi butuh orang lain untuk menyempurnakan hidupnya. Istilah tersebut kemudian diintrodusir oleh Aristoteles dengan 'zoon politicon".

Urgensitas interaksi sosial manusia kemudian menuntut agar interaksi tersebut bisa terarah dalam sebuah konsep norma. Dimana norma tersebut adalah 'batas pengatur' bahwa perilaku manusia terhadap lainnya bisa dikategorikan baik (substantif-moralis) atau justru sebaliknya, tindakan tersebut buruk (degradatifimmoralis). Untuk menghadirkan perilaku substantif-moralis, maka sangat diperlukan hadirnya agama untuk memberikan arahan kepada manusia dalam aspek teologisnormatif (doktrin) sebagai pijakan awal, dimana implementasi runtutannya dihadirkan pula norma sosial dalam dimensi sosial yang kemudian dikenal dengan istilah 'sosiologi'.

Agama dan sosiologi adalah dua entitas penting yang hadir dan beriringan dalam kehidupan manusia. Dimana agama sebagai pedoman, sedangkan sosiologi sebagai bagian dari ilmu sosial yang secara spesifik mempelajari dinamika kehidupan manusia dalam bermasyarakat, berbangsa, dan bernegara. Pendek kata, memahami agama tanpa memahami sosiologi, maka akan melahirkan sikap fundamentalis (fanatisme buta). Sebaliknya, memahami sosiologi tanpa pengetahuan agama, maka cenderung menjadi liberalissekuler.

Memahami agama (tidak terkecuali agama Islam) secara masif (kaffah) tentu menjadi keharusan bagi manusia yang 'mampu' dari berbagai macam sudut pandang yang ada. Baik, melalui teks baku keagamaan (teologis-normatif) sebagai doktrin (lafdz) yang diambil dari sumber utama (al-Qur'an dan Hadits), maupun dari hasil ijtihad para ulama lainnya, seperti yang kita kenal dengan madzhab (madzahib alarba'ah) dengan pola pendekatan syariat (eksoteric) yang dipahami dan kemudian melahirkan apa yang disebut dengan fikih (fiqh), atau pendekatan lainnya yang bernuansa tasawuf (esoteric) dalam agama itu sendiri. Tentu, sekian pendekatan agama (religion approach) diatas, semakin menemukan kesempurnaanya, ketika dilengkapi dengan sebuah pendekatan kultur sosial masyarakat yang bisa diteropong melalui praktik ajaran keagamaan yang ada dan secara tidak langsung (indirect) telah menjadi budaya (culture) yang melekat dalam setiap praktik kegamaan yang tumbuh dalam masyarakat. Dimana pendekatan tersebut dikenal dengan istilah "fenomenologi".

Artikel ini mencoba mengungkapkan salah satu metode dalam studi agama, yaitu "pendekatan Fenomenologi", dimana dalam metode ini tidak bermaksud memperbandingkan agama-agama sebagai satuan-satuan besar, tetapi lebih pada menarik fakta dan fenomena yang sama yang dijumpai dalam agama-agama yang berlainan sebagai barometer kajian melalui nalar kritis-analitis (eksperimen) yang didasarkan pada fakta empirik.

\section{Fenomenologi: Sebuah Model Pendekatan}

Menurut Muhammad Muslih (2014: 144) Istilah fenomenologi berasal dari bahasa 
Sihabuddin

Yunani, yakni phainestai yang berarti "menunjukkan" dan "menampakkan diri sendiri". Sebagai aliran epistemologi ini diperkenalkan oleh Edmund Husserl pada tahun 1859-1938. Dengan sebuah konsep "epoche"(menaruh antara tanda kurung semua pengandaian-pengandaian dan kepercayaan-kepercayaan pribadinya serta dengan simpati melihat objek yang mengarahkan diri kepadanya) dan juga konsep "eidos" (menampakkan diri atau mengkonstitusikan diri dalam kesadaran). Sebagai arus pemikiran dalam filsafat, fenomenologi ini sebelum Husserl sudah muncul semenjak tahun 1765, dan kadangkadang muncul dalam sebuah karya ahli filsafat dari Immanuel Kant. Dalam era Kant, fenomenologi ini belum dirumuskan secara khusus dan eksplisit. Makna kata "fenomenologi" ini baru semakin jelas setelah Hegel merumuskannya. Hegel mendefinisikan fenomenologi sebagai "pengetahuan sebagaimana pengetahuan itu tampil atau hadir terhadap kesadaran" (knowledge as it appears to consciousness). Selain itu, Heddy Shri Ahimsa-Putra (2012: 273-274) menjelaskan fenomenologi diartikan sebagai "ilmu pengetahuan tentang penggambaran apa yang dilihat oleh seseorang, apa yang dirasakan dan diketahuinya dalam kesadaran dan pengalamannya untuk mengungkap kesadaran fenomenal dan kesadaran mengenai fenomenamelalui ilmu pengetahuan dan filsafat menuju pemahaman yang absolut dari ilmu pengetahuan yang absolut (the absolute knowledge of the absolute). Meskipun istilah fenomenologi tidak pernah terbakukan secara tegas dalam studi agama, tapi hal terpenting bagi kita didalam menggunakan pendekatan ini, harus dilakukan dengan penuh kehati-hatian didalam menentukan faktor-faktor yang termuat dalam pendekatan fenomenologi terhadap agama. Menurut Clive Erricker (2002: 105) Pendekatan fenomenologi terhadap agama mempunyai ciri yang khas dibanding dengan disiplin-disiplin lain yang memberi pemahaman tentang subyek (agama) kepada kita, dimana tujuan yang akan diungkap melalui pendekatan fenomenologi ini untuk menggali alasanalasan historis dan epistemologis. Dan, hal ini akan memberikan pemahaman kepada kita mengapa agama menjadi suatu subyek studi dan menjadi entitas tersendiri untuk diteliti.

Clive Erricker (2002: 106) Revolusi dalam pemikiran yang dikenal dengan istilah "Enlightment"mengubah perdebatan epistemologis dan secara mendasar ditunjukkan dalam tulisan-tulisan Rousseau, Kant, dan Hume. Konstruk perdebatan tersebut telah memunculkan disiplin akademik baru sosiologi, dan psikologi. Bersamaan dengan munculnya lapanganlapangan "studi ilmiah" itu dan dipengaruhi oleh gerakan-gerakan baru dalam filsafat. Fenomenologi muncul dan digunakan dalam studi agama sebagai "suatu metode" penelitian ilmiah yang dilawankan dengan pendekatan-pendekatan teologis.

Sebagai bagian integral didalam memahami fenomenologi, maka diperlukan pemahaman dan pengetahuan tentang histroris fenomenologi itu sendiri. Jacques Waardenberg dalam penelitiannya "Classical Approaches to the Study of Religion (1973) menyimpulkan bahwa historis merupakan teks substantif. Dia mengatakan :
"Untuk menjadikan "agama" sebagai subjek penelitian empiris dan mulai menelitinya sebagai realitas manusia, niscaya menuntut tidak hanya upaya yang sungguh- sungguh tetapi juga keteguhan hati dan keberanian...salah satu lapangan utama yang secara tradisional dianggap "irasional" dibuka tidak hanya terhadap 
penelitian filosofis tetapi juga penelitian rasional" (Clive Erricker, 2002: 106)

Waardenberg menggunakan dua term kunci, yakni "empiris" dan "rasional". Empiris mengacu pada pengetahuan yang didapat melalui penelitian ilmiah - sebagai sebuah metode - yang diderivasi dari ilmuilmu kealaman dan diaplikasikan kedalam ilmu-ilmu sosial sebagai suatu pengujian terhadap struktur sosial dan perilaku manusia. Sedangkan rasional mengacu pada penelitian perilaku manusia sesuai dengan premis-premis dan penemuan pengetahuan ilmiah. Irasionalitas mengindikasikan agama sebagai suatu "fenomena" yang tidak berjalan sesuai dengan parameter-parameter tersebut. Oleh karena itu, tugas fenomenolog menunjukkan bahwa agama perlu dikaji secara serius dan memberi kontribusi terhadap pemahaman kita tentang "humanitas" dengan cara yang positif. Lebih lanjut, Waardenberg mengatakan :

"Sebagai mahasiswa agama, kita mesti tetap menyadari kenyataan bahwa konspe "agama" merupakan bagian dari kita. Dalam seluruh karyanya para cendekiawan sampai pada ide atau image tertentu tentang agama yang mereka kaji, sebagian diperoleh lewat kekuatan generalisasi, dan sebagian melalui pemahaman agama yang mereka peroleh dari pengalaman hidupnya sendiri, mereka sampai pada suatu pandangan tentang agama pada umumnya" (Clive Erricker, 2002: 107)

Hal ini mengharuskan kita semua tanggap bahwa studi agama tidak dapat menjadi penelitian yang murni objektif, tetapi harus mempertimbangkan keterlibatan peneliti dalam subjek penelitian itu sendiri. Hal ini memunculkan sebuah pertanyaan metodologis, apakah studi agama merupakan penelitian ilmiah?, Waardenberg menyampaikan sebagai berikut:
“...pertanyaan metodologis sesungguhnya muncul ketika cara pembelajaran dan penelitian yang mapan mulai kehilangan keterbuktian dirinya (self-evidence) yakni status kebenaran yang tidak dipertanyakan...Dalam banyak kasus, terdapat perdebatan mendasar diantara beragam kecenderungan pemikiran atau terjadi konflik antara pendekatan yang berbeda-beda terhadap subjek yang sama" (Clive Erricker, 2002: 108).

Sejalan dengan pemikiran Waardenberg, Levy-Bruhl menemukan pembedaan antara pemikiran "rasional" dan "primitif" yang diderivasikan dari studi-studinya tentang masyarakat "pratulisan". Dia mengatakan:

"Oleh karena itu, manusia primitif yang hidup dan berbuat dalam suatu lingkaran "ada" (being)...dipenuhi dengan sifat-sifat mistik...fenomena ini berlaku dimanapun di kalangan masyarakat yang belum berkembang....maka kita memiliki cukup otoritas untuk mengatakan bahwa mentalitas ini berbeda dari mentalitas kita. Singkatnya, pemikiran logis sedikit banyak secara sadar, menunjukkan satu kesatuan sistematik yang merupakan hal paling nyata dalam ilmu dan filsafat...sekarang materiil ini tidak terdapat dalam pikiran primitif" (Clive Erricker, 2002: 108-109).

Kajian terhadap agama (studi agama) yang dilakukan oleh Levy-Bruhl melalui penelitiannya yang membedakan antara "rasional" yang berkonotasi positif dengan "primitif" yang berkonotasi negatif/buruk, tidak lepas dari pengaruh para antropolog seperti Taylor dan Mauss. Disamping itu juga, Levy-Bruhl juga dipengaruhi oleh model evolusioner perkembangan manusia 
Sihabuddin

yang puncaknya direpresentasikan oleh peradaban Barat kontemporer. Dia berupaya mengungkap tipologi agama berdasarkan praktik-praktik, mite, dan keyakinan yang ditunjukkan oleh agamaagama yang berbeda. Dengan demikian, penelitian terhadap tipologi agama yang digagas oleh Levy-Bruhl ini akan melahirkan suatu ilmu perbandingan agama-agama yang ada di dunia yang nantinya berguna terhadap studi agamaagama yang dilakukan para mahasiswa dan sarjana kontemporer yang berminat terhadap kajian agama pada ranah empiris melalui praktik-praktik keagamaan yang diteliti.

Fenomenologi agama tidak bermaksud memperbandingkan agama-agama sebagai satuan-satuan besar, melainkan menarik fakta dan fenomena yang sama yang dijumpai dalam agama-agama yang berlainan, mengumpulkan, dan mempelajarinya per kelompok. Tujuannya untuk memperoleh gambaran yang dalam dan seksama, sebab lewat pertimbangan bersama dalam suatu kelompok, data itu akan memperjelas satu sama lain. fenomenologi tidak hanya mempertimbankan konteks historis, melainkan juga hubungan struktural dari penganut agama-agama itu sendiri. Dalam hal ini, perlu dibedakan antara "sejarah agama" dengan "sejarah dari agama tertentu". Namun, perlu kita sadari, bahwa antara fenomenologi dengan sejarah adalah satu kesatuan yang saling melengkapi. Hal ini seperti yang disampaikan oleh Raffaele Pettazzoni:

"Fenomenologi dan sejarah saling melengkapi satu sama lain. Fenomenologi tak dapat bekerja tanpa etnologi, filologi, dan disiplin sejarah lainnya. Fenomenologi dari lain pihak memberikan kepada ilmu sejarah, pengertian keagamaan yang tak dapat dicapai olehnya. Bila kita mengerti demikian, maka fenomenologi agama adalah pemahaman (Verstandniss) religius mengenai sejarah: adalah sejarah dalam dimensi religiusnya. Fenomenologi agama dan sejarah bukanlah dua ilmu melainkan dua aspek yang saling melengkapi dari suatu ilmu yang menyeluruh mengenai agama, dan ilmu agama yang demikian ini mempunyai suatu ciri yang pas yang ditentukan baginya oleh objek penyelidikannya yang khas" (Mariasusai Dhavamony, 1995: 2628).

Memahami agama dengan metode fenomenologi tersebut, tidak kemudian memilih "antara fenomenologi agama atau sejarah agama", melainkan menaruh keduanya dalam kerjasama, analogi dan hubungan timbal balik. Ketegangan diantara mereka yang mencoba memahami hakikat dan struktur dengan mereka yang mencoba memahami sejarah dari fenomena keagamaan menurut asal-usul dan perkembangannya adalah sehat, sejauh hal itu membuat ilmu agama tumbuh dari dalam dan melepaskan diri dari dogmatisme dan kebuntuan.

Fenomenologi agama tidak membatasi diri pada verifikasi dan penjelasan anlitis dari masing-masing data, sebagaimana disiplin ilmu lain yang khusus membahas persoalan agama. Tapi, fenomenologi ini berusaha mengkoordinasikan data religius untuk menentukan hubungan dan mengelompokkan fakta menurut hubungan tersebut. Kalau hubungan tersebut menyangkut persoalan forma, maka fenomenologi agama akan mengklasifikasikan data religius di bawah tipe-tipe, hal ini agama hanya bersifat "dekriptif". Kalau sifatnya kronologis, maka data tersebut dikategorikan/masuk dalam rangkaian/serial. Kalau perhubungan yang diselidiki bersifat kronologis (rangkaian kejadian ada hubungannya dengan perkembangan dari dalam), maka ilmu

112 Autentik: Jurnal Pengembangan Pendidikan Dasar, Vol.2, No.2, Juli 2018 
agama menjadi ilmu sejarah, yakni sejarah agama (Mariasusai Dhavamony, 1995: 31).

Sebagai sarana interpretasi yang utama didalam memahami arti dari ekspresiekspresi religius, maka pengikut fenomenologi agama menjadikan komparasi untuk memahaminya. Mereka mencoba menyelidiki karakteristik yang dominan dari agama dalam konteks historis-kultural. Tujuannya untuk menemukan struktur yang mendasari fakta sejarah dan memahami maknanya yang lebih dalam, sebagaimana dimanifestasikan lewat struktur tersebut dengan hukum-hukum dan pengertiannya yang khas. Secara ringkas, metode ini mencoba menangkap dan menginterpretasikan setiap jenis perjumpaan manusia dengan yang suci. Fenomenologi agama adalah ilmu empiris, ilmu manusia yang menggunakan hasilhasil ilmu manusia lainnya seperti psikologi religius, sosiologi, dan antropologi religius. Lebih dari itu, fenomenologi agama bisa dikatakan lebih dekat dengan filsafat agama daripada ilmu-ilmu manusia lainnya, yang mempelajari fenomena religius dalam aspek yang khas dari praktik kereligiusan (Mariasusai Dhavamony, 1995: 42-43).

\section{Fenomenologi dalam Studi Islam}

Dalam mengkaji Islam sebagai sebuah agama, muncul sebuah istilah yang disebut dengan insider danoutsider. Dalam perspektif muslim, insider adalah orang dalam (muslim) yang mengkaji Islam. Sedangkan outsider adalah orang luar (non muslim) yang ingin mengkaji Islam. Perbedaan keduanya (insiderdan outsider) adalah pemaknaan, bahwa insider lebih memahami tentang ajaran keagamaan yang dimiliki secara dalam dan sempurna daripada outsider yang tidak tahu karena tidak memiliki pengalaman keagamaan daripada insider tersebut. Oleh karena ruang lingkup outsider begitu sempit, maka metode yang pas dan lebih mengena untuk memahami agama diluar dirinya dengan cara pendekatan fenomenologi.

Dalam penerapan fenomenologi sebagai sebuah pendekatan yang dapat diterima untuk mengkaji agama Islam, Fazlur Rahman berpendapat bahwa al-Qur'an dan Hadits haruslah tetap menjadi titik rujukan normatif. Menurutnya, al-Qur'an dan Hadits harus dapat mengontrol bahkan memodifikasi metode fenomenologi, yang kalau tidak dimodifikasi, fenomenologi cenderung relative yang sulit untuk disembuhkan (Farhanuddin Sholeh, 2016: 351-352).

Menurut Farhanuddin Sholeh (2016: 352 353) adapun langkah-langkah menggunakan metode fenomenologi agama dalam pendekatan studi Islam, maka kita bisa menggunakan rumusan yang disusun oleh Cresswell, yaitu sebagai berikut :

1. Peneliti perlu memahami perspektif folisofis dibalik pendekatan fenomenologi, khususnya konsep tentang bagaimana orang mengalami fenomena. Konsep "epoche" adalah penting, mengurung gagasan yang telah terbentuk sebelumnya tentang suatu fenomena untuk dipahami melalui sarana-sarana informan.

2. Peneliti menulis pertanyaan-pertanyaan penelitian yang mengekspolari makna dari suatu pengalaman individu dan meminta individu untuk menggambarkan pengalaman hidup mereka sehari-hari.

3. Peneliti kemudian mengumpulkan data dari individu yang mengalami fenomena yang sedang diteliti. Informasi tersebut bisa dikumpulkan melalui wawancara yang panjang ditambah dengan refleksi dan deskripsi yang dikembangkan sebelumnya dari karya-karya artistik, dengan jumlah informan 5 hingga 25 orang. 
4. Langkah-langkah analitis data dan fenomenologis pada umumnya sama dengan semua fenomenolog psikologis yang mendiskusikan metode-metode. Semua fenomenolog psikologis menggunakan sejumlah rangkaian langkah yang sama. Rancangan prosedur dibagi kedalam pertanyaanpertanyaan atau horisonalisasi. Unit-unit kemudian ditransformasikan ke dalam cluster of meanings (kumpulan makna) yang diekspresikan dalam konsepkonsep psikologis atau fenomenologis. Terakhir, transformasi-transformasi ini diikat bersama-sama untuk membuat deskripsi umum tentang pengalaman, deskripsi tekstural tentang apa yang dialami dan deskripsi struktural tentang bagaimana yang dialami.

5. Laporan fenomenologis diakhiri dengan pemahaman yang baik dari pembaca tentang essensi yang tidak berubah dari pengalaman, sembari mengakui bahwa makna tunggal yang utuh dari pengalaman itu eksis.

Berangkat dari titik tolak historis dimana beberapa dekade terakhir studi tentang agama Islam lebih cenderung pada pemahaman teks (teologis-normatif), maka saat ini sangat dimungkinkan dan perlu kita apresiasi manakala muncul studi-studi agama, termasuk dalam Islam sendiri dengan menggunakan metode fenomenologi dengan tujuan mempelajari studi agama Islam yang dimanifestasikan dalam bentuk praktik keagamaan yang berkolaborasi dengan kehidupan sosial dan budaya masyarakat.

\section{Kesimpulan}

Fenomenologi agama merupakan pendekatan baru atau sebuah pendekatan alternatif dalam studi agama-agama di dunia, termasuk didalam studi agama Islam. Meskipun pada satu sisi, fenomenologi agama masih menjadi perdebatan dalam kalangan ilmuwan agama, tetapi pada sisi lain fenomenologi agama menghadirkan agama sebagai bagian dari obyek yang harus diteliti dan bisa dibuktikan dalam dunia empiris. Fenomenologi agama tidak bermaksud memperbandingkan agamaagama dalam satuan besar, melainkan menarik fakta dan fenomena yang dijumpai dalam agama yang berbeda. Oleh karenanya, fenomenologi agama adalah metode yang membuka ruang bagi para pemikir keagamaan di dunia untuk lebih kritis didalam mempelajari agama yang terbebas dari pikiran dan hayalan pribadi bahkan asumsi yang didasarkan pada klaim kebenaran agama-agama tertentu dan cenderung menyalahkan agama lain, termasuk didalam agama Islam itu sendiri.

\section{DAFTAR PUSTAKA}

Muslih, Muhammad. 2014. Filsafat IImu. Yogyakarta: Belukar.

Dhavamony, Mariasusai.1995. Fenomenologi Agama. Yogyakarta: Kanisius.

Erricker, Clive.2002. Pendekatan Fenomenologis. Dalam Petter Connolly (ed.), Aneka Pendekatan Studi Agama (hlm 105 - 143). Yogyakarta: LKiS.

Ahimsa-Putra, Heddy, Shri.2012. Fenomenologi Agama: Pendekatan Fenomenologi untuk Memahami Agama. Jurnal Walisongo, Vol. 20, No.2: http/www.google.com (diakses 13 Maret 2018).

Sholeh, Farhanuddin.2016. Penerapan Pendekatan Fenomenologi Dalam Studi Agama Islam. Jurnal Qolamuna, Vol. 1, No.2: http/www.google.com (diakes 13 Maret 2018)

114 Autentik: Jurnal Pengembangan Pendidikan Dasar, Vol.2, No.2, Juli 2018 